Nf $\mid \begin{aligned} & \text { Media } \\ & \text { Farmasi } \\ & \text { Poltekkes Makassar }\end{aligned}$

\title{
IDENTIFIKASI DRUG RELEATED PROBLEM'S (DRPS) PADA PASIEN DIARE DI PERAWATAN ANAK RSUD PANGKEP SULAWESI SELATAN
}

\author{
H. Asyhari Asyikin ${ }^{1}$ \\ ${ }^{1}$ Jurusan Farmasi Poltekkes Kemenkes RI Makassar \\ ${ }^{*}$ Koresponden : asyharimedifar@gmail.com
}

DOI: https://doi.org/10.32382/mf.v13i2.787

\begin{abstract}
ABSTRAK
Telah dilakukan Penelitian mengenai ini Drug Related Problems (DRPs) pada pasien diare di perawatan anak RSUD Pangkep Sulawesi Selatan pada bulan Agustus 2017. Penelitian ini termasuk penelitian jenis non-eksperimental, dan bertujuan untuk mengetahui Drug Related Problems (DRPs) pada pasien diare di perawatan anak RSUD Pangkep Sulawesi Selatan periode Januari - April 2017, pengambilan data dilakukan secara restropektif dari catatan rekam medik pasien dan dianalisis secara deskriptif. Pengambilan sampel ditentukan secara purposive sampling dengan kriteria anak yang menderita diare di Perawatan anak RSUD Pangkep periode JanuariApril 2017. Hasil penelitian menunjukkan bahwa pasien anak yang menderita diare adalah sebanyak 73 pasien yang didominasi oleh anak yang berjenis kelamin laki-laki sebanyak 42 pasien (57,53\%) dengan mayoritas pasien usia 0-1 tahun sebanyak 48 pasien (65,75\%). Jenis Drug Related Problems (DRPs) yang paling banyak terjadi adalah ketidaktepatan pemilihan obat antibiotika sebesar 20 kasus $(27,40 \%)$, diikuti indikasi tanpa obat sebesar 26,03\%, dan obat tanpa tanpa indikasi sebesar 10,96\%
\end{abstract}

Kata kunci: Diare anak, DRPs, ketidaktepatan pemilihan obat, indikasi tanpa obat, obat tanpa indikasi

\section{PENDAHULUAN}

Diare adalah salah satu penyakit yang menjadi penyebab kematian di dunia,tercatat sekitar 2,5 juta orang meninggal tiap tahun. Penyakit ini memiliki angkakejadian yang tinggi di negara berkembang, namun sedikit kejadiannya diAmerika. Dengan penanganan yang tepat infeksi diare jarang bisa menjadi suatuhal yang fatal. Agen yang dapat menyababkan diare antara lain bisa melalui tigajalur, yaitu: pada makanan, dalam air, atau penularan dari satu orang ke oranglain. Perbedaan cara penularan melalui ketiganya tergantung pada potensiketersediaannya di lingkungan tempat tinggal kita dan reflek yang diperlukanagen tersebut untuk memunculkan infeksi (Southwick, 2003).

Diare atau mencret didefi nisikan sebagai buang air besar dengan feses tidak berbentuk (unformed stools) atau cair dengan frekuensi lebih dari 3 kali dalam 24 jam. Bila diare berlangsung kurang dari 2 minggu, disebut sebagai diare akut. Apabila diare berlangsung 2 minggu atau lebih, digolongkan pada diare kronik. Feses dapat dengan atau tanpa lendir, darah, atau pus. Gejala penyerta dapat berupa mual, muntah, nyeri abdominal, mulas, tenesmus, demam, dan tanda-tanda dehidrasi (Amin, 2015).

Diare dapat juga didefinisikan sebagai suatu kondisi dimana terjadi perubahan dalam kepadatan dan karakter tinja, atau tinja cair dikeluarkan tiga kali atau lebih perhari. (Ramaiah,2012). Diare merupakan salah satu gejala dari penyakit pada sistem gastrointestinal atau penyakit lain diluar saluran pencernaan. (Ngastiyah, 2010). Jadi diare adalah buang air besar yang frekuensinya lebih dari 3 kali sehari dengan konsistensi tinja yang encer.

Berdasarkan penyebabnya, diare dapat dibedakan beberapa jenis diare yaitu diare akibat virus, bakteri, parasit, enterotoksin, dan diare yang disebabkan oleh alergi makanan atau minuman, gangguan gizi, kekurangan enzim, dan dapat pula karena pengaruh psikis (diare non spesifik) (Tjay dan Rahardja, 2002). Diare infeksi akut diklasifi kasikan secara klinis dan patofi siologis menjadi diare non inflamasi dan diare inflamasi. Diare inflamasi disebabkan 
invasi bakteri dan sitotoksin di kolon dengan manifestasi sindrom disentri dengan diare disertai lendir dan darah. Gejala klinis berupa mulas sampai nyeri seperti kolik, mual, muntah, demam, tenesmus, serta gejala dan tanda dehidrasi (Amin, 2015).

Diare dapat terjadi akibat lebih dari satu mekanisme. Pada infeksi bakteri setidaknya ada dua mekanisme, yaitu peningkatan sekresi usus dan penurunan absorbsi di usus. Infeksi bakteri menyebabkan inflamasi dan mengeluarkan toksin yang menyebabkan terjadinya diare. Infeksi bakteri yang invasif mengakibatkan perdarahan atau adanya leukosit dalam feses. Pada dasarnya, mekanisme diare akibat kuman enteropatogen meliputi penempelan bakteri pada sel epitel dengan atau tanpa kerusakan mukosa, invasi mukosa, dan produksi enterotoksin atau sitotoksin. Satu jenis bakteri dapat menggunakan satu atau lebih mekanisme tersebut untuk dapat mengatasi pertahanan mukosa usus (Amin, 2015). Oleh karena itu pengobatan diare sangat bervariasi, tergantung dari penyebab diare tersebut.

Pemberian obat yang tidak tepat dengan kondisi pasien, mengakibatkandampak negatif baik dari segi kesehatan (memperburuk kondisi pasien) serta segiekonomis (pemborosan). Penyebab DRPs kategori ini antara lain indikasi medis yang tidak tepat, serta pasien menerima obat yang tidak efektif atau kontraindikasi dengan kondisi pasien (Strand et al., 1998).

Kejadian kesalahan dalam pengobatan serta resiko kesalahan yang serius lebih sering terjadi pada anak dibanding pada orang dewasa. Hal itu disebabkan dengan masalah perhitungan dosis, tidak adanya standar dosis bagi pasien anak, tidak terdapat bentuk sediaan dan formulasi yang sesuai serta penggunaan indikasi maupun dosis obat secara 'offlicence' (Prest, 2009).

RSUD Pangkep Sulawesi Selatan merupakan sebuah rumah sakit pemerintah yang terletak di kota Pangkep. Berdasarkan observasi di RSUD Pangkep, menunjukkan bahwa penyakit diare merupakan salah satu penyakit yang masuk dalam lima besar di Rumah Sakit ini. Oleh karena itu peneliti tertarik untuk melakukan penelitian ini.

Penelitian tentang kejadian DRPs pada pengobatan diare pada pasien anak belum pernah dilakukan di Rumah Sakit ini ini sehingga kasus tersebut perlu diambil sebagai bahan penelitian. Oleh karena itu dilakukan penelitian tentang Studi Drug Related Problems (DRPs) pada pasien diare di perawatan anak RSUD Pangkep Sulawesi Selatan

Berdasarkan uraian diatas, maka timbul permasalahan bagaimana angka kejadian DRPs pada pengobatan diare di perawatan anak RSUD Pangkep pada periode Januari sampai April 2017 ?

Tujuan penelitian ini adalah untuk mengetahui adanya Drug Related Problems (DRPs) pada pasien diare di perawatan anak RSUD Pangkep Sulawesi Selatan periode Januari-April 2017. Dimana Tujuan khususnya adalah mengetahui karakteristik pasien anak penderita diare yang dirawat inap di RS ini serta mengetahui persentase kejadian Drug Related Problems (DRPs) pada pasien anak penderita diare di perawatan anak RSUD Pangkep Sulawesi Selatan kategori indikasi tanpa obat, obat tanpa indikasi, dan ketidaktepatan pemilihan obat periode Januari-April 2017. Adapun manfaat yang diharapkan dari penelitian ini adalah Sebagai bahan pertimbangan ataupun kebijakan dalam peresepan obat diare dan mencegah terjadinya DRPs khususnya pada pasien anak penderita diare, sehingga dapat meningkatkan kepercayaan masyarakat terhadap pelayanan di RSUD Pangkep Sulawesi Selatan .

\section{METODE DAN BAHAN}

\section{Jenis Penelitian}

Penelitian ini adalah observasional deskriptif di RSUD Pangkep Sulawesi Selatan , dimana data catatan rekam medik/resep pasien anak diare diambil secara retrospektif selama periode Januari sampai April 2017.

\section{Lokasi dan Waktu Penelitian}

Penelitian ini dilaksanakan di Apotek RSUD Pangkep Sulawesi Selatan pada bulan Agustus 2017.

\section{Populasi dan Sampel}

\section{Populasi}

Populasi dalam penelitian ini yaitu adalah seluruh catatan rekam medik pasien diare di Ruang Perawatan Anak RSUD Pangkep Sulawesi Selatan . 


\section{Sampel}

Sampel dalam penelitian ini ini adalah catatan rekam medik pasien diare di Ruang Perawatan Anak RSUD Pangkep periode Januari - April 2017.

\section{Jenis dan Sumber Data}

Data penelitian ini berupa data sekunder yang sumber datanya dikumpulkan dengan catatan rekam medik pasien diare di Ruang Perawatan Anak RSUD Pangkep periode Januari - April 2017.

\section{Metode Pengumpulan Data}

Pengumpulan data berupa data rekam medik pasien diare di Ruang Perawatan Anak RSUD Pangkep periode Januari - April 2017 kemudian dicatat seluruh obat yang diberikan meliputi karakteristik pasien, diagnosis penyebab diare yang didukung oleh laboratorium, dan jenis obat yang diberikan dan melihat adanya Drug Related Problems (DRPs) yang disebabkan oleh adanya indikasi tanpa obat, obat tanpa indikasi dan ketidaktepatan pemilihan obat pada pasien diare di Ruang Perawatan Anak RSUD Pangkep periode Januari - April 2017.

\section{Analisis dan Pengolahan Data}

Data yang terkumpul selanjutnya dianalisis berdasarkan studi literatur untuk melihat kemungkinan adanya DRPs, kemudian dihitung masing-masing presentasinya dan disajikan dalam bentuk tabel yang dilanjutkan dengan pembahasan dan penarikan kesimpulan.

\section{Definisi Operasional}

Pada penelitian ini, yang dimaksud dengan :

1. Pasien diare anak adalah pasien yang berumur $\leq 12$ tahun dan dirawat inap di perawatan anak RSUD Pangkep pada periode Januari - April 2017.

2. DRPs adalah kejadian yang tidak diharapkan pada pasien anak diare RSUD Pangkep, kategori DRPs yang diamati meliputi indikasi tanpa obat, obat tanpa indikasi dan ketidaktepatan pemberian obat.

3. Indikasi tanpa obat, indikatornya adalah adanya keluhan/diagnosa penyakit tapi pasien tidak diberi obat

4. Obat tanpa indikasi, indikatornya adalah pasien diberi obat tertentu sebagai tambahan tanpa adanya keluhan yang sesuai dengan tujuan penggunaan obat tersebut

5. Ketepatan pemberian obat, indikatornya adalah adanya pemberian obat khususnya antibiotik pada pasien diare akut non spesifik.

\section{HASIL DAN PEMBAHASAN \\ Hasil Penelitian}

Berdasarkan hasil penelitian yang telah dilakukan di RSUD Pangkep Sulawesi Selatan diperoleh data sebagai berikut :

Tabel 1. Jumlah penderita berdasarkan jenis kelamin

\begin{tabular}{cccc} 
No. & Jenis kelamin & Jumlah pasien & Persentase \\
\hline 1. & Laki-laki & 42 & 57,53 \\
2. & Perempuan & 31 & 42,47 \\
\hline & Total pasien & 73 & 100 \\
\hline
\end{tabular}

Sumber : Data Sekunder, 2017

Tabel 2. Jumlah penderita berdasarkan usia

\begin{tabular}{cccc}
\hline No. & Usia & Jumlah pasien & Persentase \\
\hline 1. & $0-1$ tahun & 48 & 65,75 \\
2. & $2-5$ tahun & 15 & 20,55 \\
3. & $6-12$ tahun & 10 & 13,70 \\
\hline & Total pasien & 73 & 100 \\
\hline
\end{tabular}

Sumber : Data Sekunder, 2017 
Tabel 3. Pengelompokan Diare Berdasarkan Jenisnya

\begin{tabular}{ccc}
\hline Jenis diare & Jumlah pasien & Persentase \\
\hline Diare akut spesifik & 13 & 17,81 \\
Diare akut non spesifik & 60 & 82,19 \\
\hline Total & 73 & $100 \%$ \\
\hline Sumber : Data Sekunder, 2017 &
\end{tabular}

Tabel 4. Terapi pengobatan pada pasien anak diare di RSUD Pangkep

\begin{tabular}{cccc}
\hline Kelas terapi & Nama generik & Jumlah kasus & $\begin{array}{c}\text { Persentase } \\
(\mathrm{n}=73)\end{array}$ \\
\hline Elektrolit & Infus RL & 26 & 35,62 \\
& Infus Kaen & 52 & 71,23 \\
& Infus Asering & 9 & 12,33 \\
& Infus Dekstrosa & 6 & 8,22 \\
\hline Suplemen & Zink & 52 & 71,23 \\
\hline Probiotik & Lacto B & 15 & 20,55 \\
\hline Antimikroba/ & Cefotaxime & 6 & 8,22 \\
Antibiotik & Gentamisin & 3 & 4,11 \\
& Ampcillin & 36 & 49,32 \\
& Metronidazol & 5 & 6,85 \\
& Kotrimoksazol & 45 & 61,64 \\
& Seftriakson & 2 & 2,74 \\
& Eritromisin & 5 & 6,85 \\
\hline Antiemetik & Domperidon & 34 & 46,58 \\
& Ondansentron & 3 & 4,11 \\
\hline Antipiretik & Parasetamol & 48 & 65,75 \\
\hline Sumber : Data Sekunder, 2017 & &
\end{tabular}

Tabel 5. Persentase parameter tepat indikasi dan tidak tepat indikasi pemberian antibiotik pada pasien anak diare

\begin{tabular}{|c|c|c|c|c|}
\hline $\begin{array}{l}\text { Ketepatan } \\
\text { indikasi }\end{array}$ & Diagnosa utama & Keterangan & Jumlah kasus & $\begin{array}{l}\text { Persentase } \\
(\mathrm{n}=73)\end{array}$ \\
\hline \multirow{3}{*}{ Tepat indikasi } & Diare akut spesifik & Mendapatkan antibiotik & 13 & 17,81 \\
\hline & $\begin{array}{l}\text { Diare akut disertai } \\
\text { demam }\end{array}$ & Mendapatkan antibiotik & 34 & 46,57 \\
\hline & $\begin{array}{l}\text { Diare akut non } \\
\text { spesifik }\end{array}$ & $\begin{array}{l}\text { Tidak mendapatkan } \\
\text { antibiotik }\end{array}$ & 6 & 8,22 \\
\hline \multirow{2}{*}{$\begin{array}{l}\text { Tidak tepat } \\
\text { indikasi }\end{array}$} & $\begin{array}{l}\text { Diare akut non } \\
\text { spesifik }\end{array}$ & Mendapatkan antibiotik & 20 & 27,40 \\
\hline & Diare akut spesifik & $\begin{array}{l}\text { Tidak mendapatkan } \\
\text { antibiotik }\end{array}$ & - & 0 \\
\hline & Total & & 73 & 100 \\
\hline
\end{tabular}

Sumber : Data Sekunder, 2017 
Tabel 6. Persentase parameter tepat indikasi dan tidak tepat indikasi pemberian antiemetik pada pasien anak diare

\begin{tabular}{cccc}
\hline $\begin{array}{c}\text { Ketepatan } \\
\text { pengobatan }\end{array}$ & Keterangan & Jumlah kasus & $\begin{array}{c}\text { Persentase } \\
(\mathrm{n}=73)\end{array}$ \\
\hline Tepat & Diberi antiemetik & 33 & 45,21 \\
Tidak tepat & Indikasi tanpa obat & 14 & 19,18 \\
& Obat tanpa indikasi & 4 & 5,48 \\
\hline
\end{tabular}

Sumber : Data Sekunder, 2017

Tabel 7. Persentase parameter tepat indikasi dan tidak tepat indikasi pemberian analgetik pada pasien anak diare

\begin{tabular}{cccc}
\hline $\begin{array}{c}\text { Ketepatan } \\
\text { pengobatan }\end{array}$ & Keterangan & Jumlah kasus & $\begin{array}{c}\text { Persentase } \\
(\mathrm{n}=73)\end{array}$ \\
\hline Tepat & Diberi antipiretik & 43 & 58,90 \\
Tidak tepat & Indikasi tanpa obat & 5 & 6,85 \\
& Obat tanpa indikasi & 4 & 5,48 \\
\hline
\end{tabular}

Tabel 8. DRPs yang terjadi pada pasien diare di Perawatan Anak RSUD Pangkep periode Januari-April 2017

\begin{tabular}{|c|c|c|c|}
\hline Parameter & Indikator & Jumlah kasus & $\begin{array}{l}\text { Persentase } \\
(\mathrm{n}=73)\end{array}$ \\
\hline \multirow{4}{*}{$\begin{array}{l}\text { Ketidaktepatan } \\
\text { pemilihan obat } \\
\text { Indikasi tanpa obat }\end{array}$} & $\begin{array}{l}\text { Diare akut non spesifik } \\
\text { diberi antibiotik }\end{array}$ & 20 & 27,40 \\
\hline & $\begin{array}{l}\text { Mual/muntah tanpa } \\
\text { antiemetik }\end{array}$ & 14 & 19,18 \\
\hline & $\begin{array}{l}\text { Ddmam tidak diberi } \\
\text { antipiretik }\end{array}$ & 5 & 6,85 \\
\hline & Jumlah & 19 & 26,03 \\
\hline \multirow[t]{3}{*}{ Obat tanpa indikasi } & $\begin{array}{l}\text { Diberi antiemetik tanpa } \\
\text { keluhan mual/muntah }\end{array}$ & 4 & 5,48 \\
\hline & $\begin{array}{l}\text { Diberi antipiretik tanpa } \\
\text { keluhan demam }\end{array}$ & 4 & 5,48 \\
\hline & Jumlah & 8 & 10,96 \\
\hline
\end{tabular}

\section{Pembahasan}

Dalam penelitian ini proses penelusuran data dilakukan dengan cara mengamati data rekam medik pasien. Tahap pertama untuk mengambil sampel dilakukan adalah pemilihan sampel dari populasi pasien anak yang terkena diare, pipulasi penelitian ini adalah seluruh pasien anak yang diare yang dirawat inap di RSUD Pangkep periode Januari sampai dengan April 2017 yaitu sebanyak 73 pasien. Jumlah sampel yang diamati pada penelitian ini adalah seluruh pasien anak yang menderita diare yang dirawat yaitu sebanyak 73 pasien (total sampling).

Pasien digolongkan menderita diare akut spesifik jika:1) dalam data rekam medik tertulis diare akut spesifik seperti misalnya disentri. 2) didalam data rekam medik tertulis lendir dan darah dalam feses, namun dalam penelitian ini data yang tertulis hanya diare akut meskipun ada lendir dan darah dalam rekam medik pasien. Oleh karena itu pasien yang menderita diare akut spesifik pada penelitian ini didasarkan pada adanya lendir dan darah pada catatan rekam medik pasien. Seperti yang tersaji dalam tabel 3.

\section{Karakteristik pasien}

Berdasarkan data pada Tabel 1, diketahui lebih banyak pasien anak diare berjenis kelamin laki-laki yaitu sebanyak $57,53 \% \quad$ (42 pasien) dibandingkan pasien berjenis kelamin perempuan sebanyak $42,47 \quad \% \quad$ (3 pasien). Hal tersebut bukan 
menunjukkan laki-laki mempunyai resiko terkena diare lebih besar dibandingkan perempuan, tetapi lakilaki dan perempuan memiliki faktor resiko yang sama terhadap diare akut (Suraatmaja, 2010).

Dari Tabel 2, menunjukkan bahwa usia paling banyak menderita diare adalah pasien yang berusia $0-1$ tahun yaitu sebanyak 48 pasien $(65,75 \%)$ dari jumlah pasien anak diare, dan sisasnya anak dengan usia 2-5 tahun sebanyak 15 pasien $(20,55 \%)$ dan usia 6-12 tahun sebanyak 10 pasien $(13,70 \%)$. Hasil penelitian sebelumnya yang dilakukan oleh Rusdi, dkk. (2009), juga menunjukkan hal yang sama bahwa usia paling banyak menderita diare adalah pasien yang berusia 0-1 tahun. Hal ini disebabkan oleh sistem imunologi dan kemampuan cadangan regenerasi sel epitel usus terbatas sehingga mukosa usus membutuhkan waktu yang lama untuk dapat pulih kembali. Selain itu karena sistem imunologik (daya tahan tubuh/kekebalan tubuh terhadap penyakit) anak rendah sehingga mudah terkena diare (Anonim, 2007 dalam Rusdi, dkk 2009).

BerdasarkanTabel 3, diketahui bahwa hasil diagnosa penderita diare anak yang tertera pada rekam medik menunjukkan jenis diare akut adalah sebanyak 82,19\% dan diare akut spesifik sebanyak $17,81 \%$.

\section{Pengobatan yang diberikan pada pasien anak diare}

Pada pasien yang menderita diare, dehidrasi merupakan gejala yang paling sering dijumpai, pemberian cairan yang tepat dengan jumlah yang memadai merupakan modal yang utama untuk mencegah dehidrasi. Cairan harus diberikan sedikit demi sedikit dengan frekuensi sesering mungkin. Hasil penelitian ini menunjukkan bahwa pengobatan diare anak menggunakan cairan rehidrasi secara parenteral yaitu ringger laktat (RL), KAEN, Asering, dan dekstrosa. Penggunaan cairan infus Kaen paling banyak digunakan untuk mengatasi dehidrasi pada pasien anak diare yaitu sebanyak 52 kasus $(71,23 \%)$ disusul dengan penggunaan cairan infus Ringer Laktat sebanyak 26 kasus $(35,62 \%)$. Pada penelitian ini tidak ditemukan penggunaan terapi rehidrasi oral (ORT). Pemberian cairan pengganti merupakan pengobatan utama pada penyakit diare yaitu dengan menggunakan cairan elektrolit (Depkes, 2010).

Pengobatan selanjutnya dengan pemberian terapi zinc, setelah penderita diare diketahui derajat dehidrasinya maka pasien diberi suplemen zinc yang berguna untuk mengurangi lama dan tingkat keparahan diare, mengurangi volume air besar, mengurangi volume tinja dan menurunkan kekambuhan diare pada tiga bulan berikutnya (Fontaine, 2008). Hasil pada Tabel 4 menunjukkan pasien yang menerima suplemen zink sebanyak 52 kasus $(71,23 \%)$. WHO dan UNICEF merekomendasikan penggunaan zink karena berdasarkan hasil penelitian diketahui bahwa pengobatan diare dengan pemberian cairan rehidrasi disertai zink lebih efektif dan berdasarkan studi WHO selama lebih dari 18 tahun, manfaat zink pada pengobatan diare adalah zink dapat mengurangi prevalensi diare sebesar $34 \%$, mengurangi durasi diare akut sebesar 20\% (Kemenkes RI, 2011).

Pengobatan menggunakan probiotik (lacto B) pada pasien anak diare di RSUD Pangkep sebanyak 15 kasus (20,55\%). Probiotik digunakan untuk mengurangi frekuensi dan durasi diare dengan meningkatkan respon imun, produksi substansi antimikroba dan menghambat pertumbuhan kuman patogen penyebab diare. Diharapkan dengan dampaknya terhadap sistem imunitas, probiotik dapat dijadikan referensi sebagai terapi tambahan yang efektif pada diare akut infeksi, mengurangi beban ekonomi dengan menurunkan frekuensi dan durasi diare sehingga menurunkan lama rawat inap di rumah sakit.

Penggunaan antibiotik pada penderita diare dibutuhkan untuk mengatasi infeksi yang disebabkan bakteri dan jamur. Pemberian antibiotik yang tidak tepat dapat membunuh flora 
normal yang justru dibutuhkan tubuh anak memiliki resiko mendapatkan efek merugikan lebih tinggi akibat infeksi bakteri karena sistem imunitas anak yang belum berfungsi secara sempurna. Beberapa antibiotik yang cocok digunakan pada orang dewasa belum tentu tepat jika diberikan kepada anakanak karena proses absorbsi, distribusi, metabolisme dan ekskresi obat termasuk antibiotik berbeda pada anak dan orang dewasa, sehingga bisa terjadi perbedaan respon terapeutik atau efek samping. Efek samping dari penggunaan antibiotik yang tidak rasional adalah timbulnya gangguan fungsi ginjal dan hati. Hal ini juga akan mengeluarkan biaya pengobatan yang seharusnya tidak diperlukan (Kemenkes, 2011). Hasil penelitian ini menunjukkan jenis antibiotik yang ditujukkan untuk terapipasien anak diare yaitu paling banyak diberikan adalah kotrimoksazol yaitu sebanyak 45 kasus $(61,64 \%)$, diikuti oleh pemberian ampisillin sebanyak 36 kasus (49,32\%), cefotaksim sebanyak 6 kasus $(8,22 \%)$, metronidazol dan eritromisin masingmasing sebanyak 5 kasus $(6,85 \%)$, gentamisin sebanyak 3 kasus $(4,11 \%)$, dan seftrikason sebanyak 2 kasus $(2,74 \%)$. Data selengkapnya dapat dilihat pada Tabel 5 .

\section{Drug Related Problems (DRPs) pada pasien anak diare}

Pada pemberian terapi untuk pasien anak diare akut dengan dan tanpa penyakit penyerta cenderung mengalami DRPs karena pada pasien anak faktor fisiologis yang belum sempurna sehingga membutuhkan perhatian khusus dalam pemberian obat-obatan. Pada masalah ini, peran farmasis sangat dibutuhkan untuk meminimalisir terjadinya DRPs pada penggunaan obat. Evaluasi DRPs sangat mendukung untuk menghindari terjadinya DRPs, evaluasi ini bertujuan untuk menjadikan pengobatan yang diberikan kepada pasien dapat mencapai efek terapi dan pasien mendapat pengobatan yang aman, berkhasiat dan bermutu (Sari Novita, 2015).
Evaluasi DRPs terdiri dari beberapa kategori yaitu : ketidak tepatan pemilihan obat, dosis obat kurang, dosis obat berlebih, indikasi tanpa obat, obat tanpa indikasi, interaksi obat, dan ketidakpatuhan pasien. Pada penelitian ini, pengkajian adanya DRPs dibatasi pada kasus ketidaktepatan pemilihan obat untuk pasien anak diare. Ketidak tepatan pemilihan obat adalah suatu keadaan dimana pasien mendapatkan terapi obat yang tidak tepat seperti obat bukan yang paling efektif, pasien alergi atau kontraindikasi dan tidak sesuai dengan kondisi patologi pasien (Sari Novita, 2015).

Data pada Tabel 8, menunjukkan bahwa terdapat 20 pasien $(27,40 \%) \quad$ yang mengalami ketidaktepatan pemberian obat, berdasarkan catatan rekam medik pasien tersebut hanya mengalami diare tanpa lendir dan darah sehingga dikategorikan sebagai diare akut non spesifik. Pada kejadian diare akut yang disebabkan oleh faktor non infeksi (malnutrisi, malabsorbsi, intoksikasi dan lain-lain), pemakaian antibiotik tidak diperlukan.

Antibiotik seharusnya tidak di indikasikan untuk diare non spesifik pada anak-anak,karena mayoritas penyebab diare adalah rotavirus yang dapat sembuh sendiri. Pilihan obat yang banyak dianjurkan dalam kasus diare non spesifik anak adalah obat rehidrasi dan suplemen zink. Kemungkinan dokter memberikan terapi antibiotika sebagai terapi empiris. Pada banyak keadaan infeksi, kuman penyebab infeksi belum dapat diketahui atau dipastikan pada saat terapi antibiotika dimulai. Pemilihan jenis antibiotika diberikan berdasarkan perkiraan kemungkinan kuman penyebabnya. Ini didasarkan pada pengalaman yang layak atau berdasarkan pada pola epidemiologi kuman setempat. Pertimbangan utama dari terapi empiris ini adalah pengobatan infeksi sedini mungkin akan memperkecil resiko komplikasi atau perkembangan lebih lanjut dari infeksinya (Santoso, 2010).

Ketepatan terapi Antibiotik di dasarkan pada hasil pemeriksaan laboratorium yang menunjukkan adanya 
infeksi bakteri, baik pada pemeriksaan urin rutin maupun pada pemeriksaan feses. Dimana disitu akan terlihat apakah terinfeksi bakteri Entamuba Coli dan Entamuba Histolitika atau tidak. Pada penanganan diare di RSUD Pangkep, tidak ditemukan adanya pemeriksaan laboratorium terhadap tinja pasien sehingga penggunaan jenis-jenis antibiotika tidak dapat dipastikan ketepatannya dalam pengobatan pasien diare anak.

Jumlah pasien dengan keluhan mual muntah sebanyak 47 kasus dan yang diberikan obat antiemetik pada kasus tersebut sebanyak 33 kasus dan tidak mendapat terapi antiemetik (indikasi tanpa obat) sebanyak 14 kasus.Jumlah pasien pasien yang diberi obat antiemetik sebanyak 37 kasus, dengan demikian ada 4 kasus $(5,48 \%)$ pemberian obat antiemetik tanpa indikasi mual/muntah. (data selengkapnya lihat Tabel 6). Berdasarkan penelitian secara RCT menunjukkan bahwa ondansetron dan domperidon dapat digunakan dalam mengobati anak-anak menderita gejala AGE (Acute Gastroenteritis). Keduanya menunjukkan khasiat yang dapat diterima anak-anak serta profil kemanan yang baik (Reksuppaphol, 2013).

Pasien anak diare dengan diagnosa tambahan demam (febris) sebanyak 48 kasus, antipiretik yang digunakan dalam pengobatan diare pada anak di RSUD Pangkepadalah parasetamol. Antipiretik diresepkan untuk pasien yang mengalami demam, pemberian parasetamol untuk anak dengan dosis $10-15 \mathrm{mg} / \mathrm{kg} /$ dosis setiap 4 sampai 6 jam dianggap aman dan efektif (Sullivan et al, 2011). Jumlah pasien dengan keluhan demam yang diberi antipiretik sebanyak 43 kasus $(58,90 \%)$, dan yang tidak diberi antipiretik (indikasi tanpa obat) sebanyak 5 kasus $(6,85 \%)$. Jumlah pasien yang mendapat terapi antipiretik sebanyak 47 kasus, dengan demikian ada 4 kasus $(5,48 \%)$ pemberian obat antipiretik tanpa indikasi demam. (data selengkapnya lihat Tabel 7).

Berdasarkan evaluasi kasus di atas, maka hasil penelitian ini menunjukkan bahwa DRPs yang terjadi pada pasien anak diare di Perawatan Anak RSUD Pangkep periode JanuariApril 2017 adalah ketidaktepatan pemilihan obat sebanyak 20 kasus $(27,40 \%)$, indikasi tanpa obat sebanyak 19 kasus (26,03\%), dan obat tanpa indikasi sebanyak 8 kasus $(10,96 \%)$ (data selengkapnya lihat Tabel 8). Adanya DRPs pada pasien anak harus menjadi perhatian tenaga kesehatan khususnya farmasis, dengan meningkatkan kerjasama dan kolaborasi dengan tenaga kesehatan lain di rumah sakit.

\section{PENUTUP}

\section{Kesimpulan}

Berdasarkan hasil penelitian dan pembahasan, maka dapat disimpulkan bahwa:

1. Pasien anak yang menderita diare di RSUD Pangkep Sulawesi Selatan periode Januari-April 2017 sebanyak 73 pasien yang didominasi oleh anak yang berjenis kelamin laki sebanyak 42 pasien $(57,53 \%)$ dengan mayoritas pasien usia 0-1 tahun sebanyak 48 pasien $(65,75 \%)$.

2. Potensi terjadinyaDrug Related Problems (DRPs) yang paling banyak terjadi adalah ketidaktepatan pemilihan obat sebesar 20 kasus $(27,40 \%)$, diikuti indikasi tanpa obat sebesar 26,03\%, dan obat tanpa tanpa indikasi sebesar $10,96 \%$

\section{Saran}

1. Perlu dilakukan kultur media pemeriksaan laboratorium terhadap faeses pasien supaya dapat diketahui penyebab diare secara spesifik, sehingga pengobatan dan pemilihan obat menjadi lebih tepat dan optimal.

2. Perlu dilakukan penelitian lebih lanjut tentang evaluasi penggunaan obat pada anak terkena diare berdasarkan kategori penyebab DRPs lainnya (ketepatan dosis, interaksi obat). Dan penelitian DRPs dengan metode yang berbeda, misalnya secara prospektif. 


\section{DAFTAR PUSTAKA}

Amin, 2015, Tata Laksana Diare Akut, Jurnal CDK/230, Vol 42 No. 7, Jakarta

Anonim, 2011, Pedoman Pelayanan Kefarmasian untuk Terapi Antibiotik, Kementrian Kesehatan Republik Indonesia, Jakarta.

Depkes RI, 2010, Hasil evaluasi program pemberantasan penyakit diare, Direktorat Pemberantasan Penyakit Menular dan Penyehatan Lingkungan Pemukiman Departemen Kesehatan, Jakarta

Fontaine O, 2008, Bukti Kemanan dan Kemajuran Suplementasi Zink pada penderita diare, www.whozincabstractofDrOfontainko nikaindonesia.Pdf, diakses Juli 2017

Kemenkes RI, 2011, Panduan Sosialisasi Tatalaksana Diare Balita, Jakarta, Direktorat Jendral Pengendalian Penyakit dan Penyehatan Lingkungan.

Ngastiyah. 2010. Perawatan Anak Sakit Edisi Dua. Penerbit Buku Kedokteran EGC. Jakarta

Prest., 2009. Penggunaan Obat Pada Anakanak. Dalam: Farmasi klinis. Editor: Aslam. Jakarta: PT Gramedia.

Ramaiah, 2012, All You Wanted to Know About Diare, Gramedia, Jakarta.
Rusdi, dkk, 2012, Evaluasi Penggunaan Obat Diare terhadap Kesesuaian Obat dan Dosis pada Pasien Anak Rawat Inap di RSUD Budhi Asih Jakarta, Jurnal Farmasains vol 1 No. 5, April, 2012,

Numlilfarmasains.uhamka.ac_.idvolume-1-no-5.pdf, diakses tanggal Juli 2017.

Santoso, B., 2010, Peta Klasifikasi Antibiotika dan Prinsip Pemilihan danPemakaiannya Dalam Klinik, 8, Laboratorium Farmakologi KlinikFakultas Kedokteran UGM, Yogyakarta.

Sari Novita, 2015, Evaluasi DRPs Obat Antidiabetes pada Pasien Geriatri dengan Diabetes Melitus Tipe 2 di Ruang Rawat Inap RSU Pelabuhan periode Januari-Juni 2014, Skripsi Fak Kedokteran dan Ilmu Kes, UIN Syarif Hidayatullah, Jakarta

Strand et al., 1998 tentang DRPs, Drug Related Problems: Their Structure Function, Amerika Serikat: Departemen of Pharmacy Practice

Suraatmaja, Sudaryat. 2007, Kapita Selekta Gastroenterologi, Sagung Seto, Jakarta

Tjay, T.H., dan Rahardja, K., 2012, ObatObat Penting Khasiat, Penggunaan,dan Efek-efek sampingnya, Edisi V, Cetakan ke II, Depkes RI, Jakarta. 